Lima, I.B. As contribuições ambientais das RPPN's e das propriedades rurais privadas participantes no turismo de natureza nos municípios de Pirenópolis e Corumbá de Goiás: uma análise comparativa. Anais do VIII Congresso Nacional de Ecoturismo e do IV Encontro Interdisciplinar de Ecoturismo em Unidades de Conservação. Revista Brasileira de Ecoturismo, São Paulo, v.4, n.4, 2011, p. 519.

\title{
AS CONTRIBUIÇÕES AMBIENTAIS DAS RPPN's E DAS PROPRIEDADES RURAIS PRIVADAS PARTICIPANTES NO TURISMO DE NATUREZA NOS MUNICÍPIOS DE PIRENÓPOLIS E CORUMBÁ DE GOIÁS: UMA ANÁLISE COMPARATIVA
}

\author{
Ismar Borges de Lima* \\ *Instituto de Estudos Socioambientais-Universidade Federal de Goiás \\ E-mail: ismarlima@yahoo.com.br
}

Desde o século XIX já existe o conceito de reservas naturais privadas em que os proprietários, por iniciativa própria, buscam salvaguardar uma parte considerável de suas terras cobertas por áreas de relevância ambiental e cênica. A primeira iniciativa do gênero foi na Inglaterra, em 1899, com a fundação da Reserva Natural Nacional de Wicken Fen, em Cambridgeshire, sob o status de um National Trust. No Brasil, projetos semelhantes foram institucionalmente estabelecidos a partir de 1990 quando o governo brasileiro apresentou novas propostas de Unidades de Conservação, o que, na verdade, só veio acontecer em 2000, com a criação do Sistema Nacional de Unidades de Conservação, SNUC, e com ele surgiu a categoria RPPN, Reserva Particular do Patrimônio Natural. No início, o Nature Conservancy teve um papel importante no encorajamento e ajuda aos proprietários que quisessem transformar suas fazendas em 'patrimônio natural legal', reconhecido por lei e, de alguma forma, amparado pelo Estado. Em Goiás, o Santuário Vagafogo foi a primeira RPPN a ser criada. Com apenas 17 hectares, a fazenda se transformou em uma das opções da região para o turismo de natureza com uma mata ciliar bem preservada e com trilhas e equipamentos necessários para uma visitação com contornos ambientais. Posteriormente, outra fazenda de Pirenópolis também foi parcialmente transformada em RPPN, a Reserva Ecológica Vargem Grande, com trilhas em meio ao Cerrado que levam a duas cachoeiras, a principal a do Lázaro. A Fazenda Bom-Sucesso é outro local onde se tem uma impressionante coleção de cachoeiras e porções de matas ciliares, além do evidente ruralismo com as rotinas da vida na fazenda, atraindo turistas o ano inteiro. No entanto, o empreendimento não é uma RPPN. O município de Pirenópolis, por causa do Cerrado ainda prístino e dos vários atrativos naturais, tal como o Parque Estadual da Serra dos Pireneus, tornou-se um roteiro para o turismo de viés ambiental, bem como para o turismo aventura, turismo rural, ou agro-rural; além do turismo histórico-cultural urbano, pois, Pirenópolis é patrimônio reconhecido pela UNESCO. É um destino com uma diversidade de apelos e de opções para o visitante que vem em grande número do Distrito Federal e de Goiânia, os principais mercados emissores. No município vizinho a Pirenópolis, encontra-se o Salto de Corumbá, um eco-Resort que tem promovido turismo de natureza de massa e de aventura, além de oferecer pacotes com educação ambiental a grupos escolares de todos os níveis e a grupos corporativos. Apesar de todos esses imperativos, o papel e as contribuições das RPPNs e das propriedades privadas envolvidas com a atividade turística precisam ainda de ser mais amplamente averiguadas em termos comparativos. É importante saber as diferentes dinâmicas e formas de gerenciamento, bem como a estrutura e os equipamentos existentes desses estabelecimentos em Pirenópolis e em Corumbá de Goiás. Para esta pesquisa, existem três elementos principais a serem observados: como o componente educacional tem sido oferecido no turismo de natureza; como essas propriedades têm contribuído de fato para a preservação ambiental do Cerrado; e se essas atividades turísticas podem ou não ser classificadas como 'ecoturismo'.

Palavras-chave: Estruturas e Equipamentos das RPPN's; Educação Ambiental; Preservação Ambiental. 